\title{
Wybrane problemy projektowania i dynamiki pojazdów szynowych PRT
}

\begin{abstract}
Artykut dotyczy nowoczesnego systemu transportowego PRT (Personal Rapid Transit). W pracy przedstawiono najważniejsze własności systemów PRT, które czyniq je potencjalnym przyszłościowym rozwiazaniem dla miejskiego transportu publicznego. Szczególnq uwage zwrócono na zagadnienia projektowania, w tym minimalizacji niekorzystnego oddziaływania drgań na organizm czlowieka. Zaprezentowano przyktadowe rozwiazanie kabiny pojazdu oraz wybrane wyniki badań symulacyjnych dynamiki ruchu pojazdu z uwzględnieniem manewru zmiany toru z prostego na zakrzywiony.
\end{abstract}

\section{Wstęp}

Problemy transportu w aglomeracjach miejskich stają się poważnymi problemami początku XXI wieku a ich rozwiązanie priorytetowymi działaniami nie mniej ważnymi niż budowa autostrad czy linii kolejowych. Mała przepustowość, zatory ruchu, kolizyjność (głównie transport samochodowy), energochłonność, zanieczyszczenie środowiska, emisja $\mathrm{CO}_{2}$, znaczne powierzchnie na infrastrukturę i rosnące koszty jej budowy, duże koszty eksploatacji, relatywnie mała odporność na zagrożenia terrorystyczne - to tylko niektóre problemy współczesnych miejskich systemów transportowych. Obecnie szczególnie dużo prac i działań poświęconych jest rozbudowie i udoskonalaniu istniejących już środków i systemów transportowych. Czy ta droga jest wystarczająca? Prawdopodobnie nie i należy poszukiwać nowych koncepcji budowy miast i środków transportu. Na świecie zaczynaja powstawać nowe projekty - „miasta laboratoria". Jednym z nich jest projekt budowy miasta Masdar w Zjednoczonych Emiratach Arabskich. Zakaz wjazdu pojazdów spalinowych do centrum, ekologiczny transport w centrum, koncepcje Park \& Ride, ,czysta energia" (geotermalna, słoneczna czy z wykorzystaniem wiatru), zakłady recyklingu to najważniejsze atrybuty. W tych nowych koncepcjach coraz częściej pojawią się systemy transportowe określane skrótem PRT - od ang. Personal Rapid Transit. [1,2] Pod tym pojęciem rozumie się transport łączący cechy transportu osobistego i masowego transportu miejskiego typu, ,point to point” lub „door to door” (tzn. pomiędzy przystankiem początkowym a końcowym nie ma żadnych przystanków pośrednich). Transport PRT realizowany jest przez małe pojazdy (czteroosobowe) poruszające się zdalnie po lekkiej infrastrukturze - najczęściej szynie napowietrznej. Pojazdy sterowane sa zdalnie i wybierają optymalną drogę podróży. Jednak system PRT nie jest nową koncepcją. Pojawiła się ona w USA w latach pięćdziesiątych a za ojca PRT uważa się Donn'a Fichtera - planistę transportu miejskiego w USA. Pierwsze próby wdrożenia PRT, z wielu przyczyn zakończyły się niepowodzeniem.

Rozwój technologii informatycznych i materiałowych, jak również rzeczywiste potrzeby spowodowały, że obecnie wiele nowych rozwiązań jest na etapie badań, symulacji i przygotowań do wdrożenia. Obecnie na świecie można obserwować współzawodnictwo we wdrożeniu komercyjnych linii PRT. Prawdopodobnie pierwsza wdrożona zostanie brytyjska ULTRA.

Należy szczególnie silnie podkreślić, że w tych nowych rozwiązaniach szczególna uwaga zostaje skierowana na neutralność ekologiczną tych systemów oraz komfort i bezpieczeństwo pasażera w tym pasażera niepełnosprawnego.

$\mathrm{Na}$ Politechnice Warszawskiej rozpoczęto prace nad budową polskiej wersji systemu PRT (zwanego SITIN - System Indywidualnego Transportu Inteligentnego i Napowietrznego) [3,4]. Prace znajdują się w fazie wstępnej.

W niniejszym artykule przedstawiono pewne założenia do budowy systemu SITIN oraz wyniki pierwszych analiz symulacyjnych.

\section{Podstawowe założenia projektowe systemu SITIN}

System PRT-SITIN realizowany będzie z wykorzystaniem pojazdów czteroosobowych lub sześcioosobowych poruszających się z wykorzystaniem napędu elektrycznego na szynie napowietrznej. Kierowanie pojazdów odbywać się będzie zdalnie bez udziału człowieka. Podstawowe znaczenie dla systemów PRT mają rozjazdy umożliwiające zmianę kierunku jazdy. Rozjazdy mają być statyczne - niewymagające żadnych elementów ruchomych. Zmiana kierunku jazdy 
realizowana będzie poprzez specjalne mechanizmy, w które wyposażony jest układ jezdny pojazdu.

Sieć „dróg” dla pojazdów PRT jest dwuwarstwowa (Rys. 1.) i składa się z warstwy I, w skład której wchodzą tzw. magistrale główne, po których poruszają się pojazdy ze stałą prędkością (około $50-60 \mathrm{~km} / \mathrm{h}$ ) i warstwy II w skład której wchodzą drogi, po których pojazdy poruszają się z mniejszą prędkością (od 0 do $50 \mathrm{~km} / \mathrm{h}$ i która realizuje istotę transportu „door to door" tzn. transport pasażera od miejsca w bezpośredniej bliskości jego przebywania na początku podróży do miejsca bezpośredniej bliskości miejsca docelowego podróży).

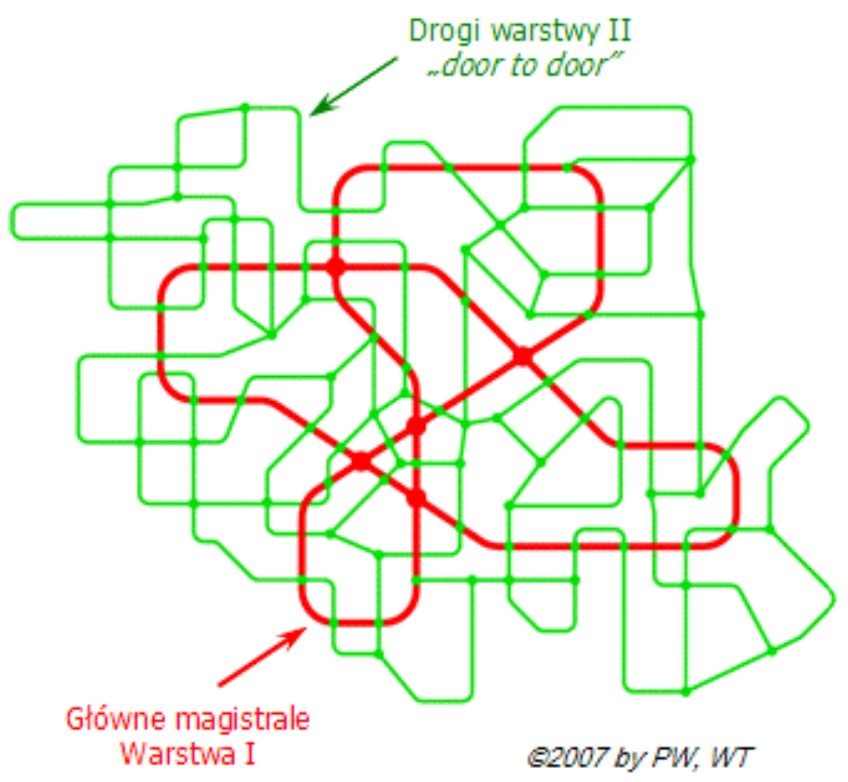

Rys. 1 Dwuwarstwowa sieć „dróg” dla pojazdów PRT

Prędkość zjazdu z warstwy I do warstwy II nie powinna opóźniać ruchu na magistrali głównej oraz nie powinna powodować efektów niedopuszczalnych z punku widzenia oddziaływania niezrównoważonego przyspieszenia na człowieka oraz szybkości jego zmian tzw. ,jerk”. Przy projektowaniu pojazdów PRT zachowano zgodność z wymogami ergonomicznymi oraz uwzględniono wymagania osób niepełnosprawnych (w szczególnym przypadku po złożeniu siedzisk - wjazd wózka inwalidzkiego z osobą obsługująca ten wózek).

System sterowania powinien zapewnić, by pojazdy PRT były w ruchu tyko w przypadku gdy: realizują zadanie przewozowe, jadą na konkretny przystanek (wezwanie), by zrealizować zadanie przewozowe, jadą do miejsc składowania (garażowania, gdzie znajdują się w stanie obsługi lub oczekiwania na realizację zadania przewozowego).

Infrastruktura systemu poprzez lekkość jest łatwa do implementacji w typowych miastach polskich (duże aglomeracje oraz średnie miasta i miastakurorty).
Główne założenia konstrukcyjne układu jezdnego pojazdu PRT są przedmiotem wynalazku, którego twórcami są autorzy referatu. Schemat ogólny tego rozwiązania konstrukcyjnego pokazano na rysunku 2. Pojazd składa się z kabiny (1) zamocowanej poprzez element thumienia drgań (2) do układu jezdnego/nośnego (3) przemieszczającego się w zespolonej prowadnicy (4). Układ jezdny (3) posiada trzypunktowe prowadzenie poprzez punkty/węzły A, B, C, które nadają ustalony kierunek ruchu pojazdu.

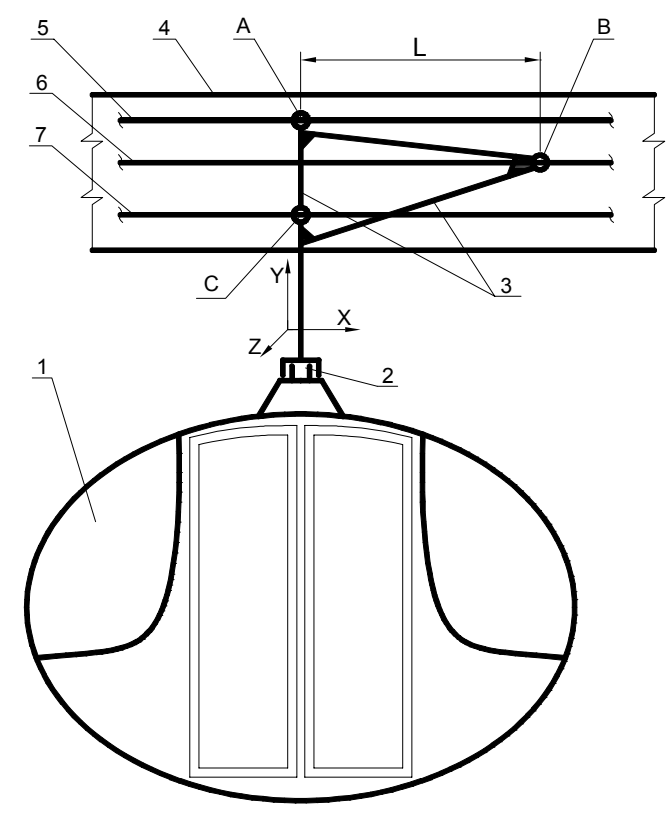

Rys. 2 Schemat ogólny opatentowanego rozwiązania konstrukcyjnego

Charakterystyczne jest to, że punkt/węzeł B (Rys. 2.) położony jest w odległości L od linii łączącej punkty A, C, w kierunku osi OX przedstawionego poniżej układu współrzędnych. Zespoły rolek/kół prowadzących umieszczonych w punktach/węzłach A, B, C poprzez ich odpowiednie sterowanie pozwalaja na realizację wybranej trasy ruchu pojazdu $\mathrm{w}$ sieci napowietrznych nieruchomych, statycznych szyn jezdnych $(5,6,7)$ zabudowanych w zespolonej prowadnicy (4).

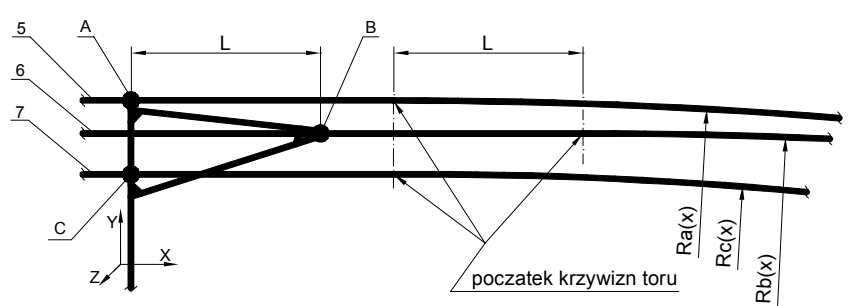

Rys. 3 Prowadzenie pojazdu SITIN 
Układ statycznych szyn nośnych 5, 6, 7 jest znamienny tym, że wzajemne ustawienie i geometria w/w nieruchomych szyn pozwala na przyjęcie przez układ jezdny, a poprzez to kabinę, położenia, które będzie najkorzystniejsze z punktu prowadzenia pojazdu. Takie rozwiązanie konstrukcyjne pozwala na prowadzenie pojazdu po ściśle określonej trasie ze ściśle określonymi położeniami kątowymi kabiny, co pozwala na nadanie kątów przechyłu kabiny zmniejszające odczucia sił odśrodkowych i bezwładności. Dotyczy to ruchu w płaszczyźnie XY oraz w płaszczyźnie XZ przedstawionego powyżej układu współrzędnych. Zalety opatentowanego rozwiązania konstrukcyjnego to:

- Układ jezdny zapewnia możliwość wyboru toru jazdy poprzez mechanizmy zawarte w nim

- Układ jezdny umożliwia zachowanie pożądanego kierunku przechyłu pojazdu w płaszczyźnie XY co jest korzystne przy pokonywaniu wzniesień $\mathrm{i}$ spadków powiązanych ze zmianą wysokości na jakiej podróżuje pojazd

- Układ jezdny zapewnia możliwość nadawania pożądanego kierunku przechyłu pojazdu w płaszczyźnie YZ co jest korzystne przy pokonywaniu zakrętów przez pojazd

- Pojazd zapewnia komfort podróżowania poprzez zastosowanie elementu tłumienia drgań kabiny w obszarze mocowania pojazdu do układu jezdnego.

Opisany powyżej schemat układu jezdnego posiada zintegrowane trzy zespoły rolek A, B, C, które umieszczone są odpowiednio w węzłach $\mathrm{A}, \mathrm{B}, \mathrm{C}$. Przedstawione rozwiązanie charakteryzuje się tym, że posiada jednoosiowy wózek jezdny w węźle A z prowadzeniem rozmieszczonym odpowiednio we wszystkich trzech węzłach A,B,C. Zmiana strony prowadzącej odbywa się poprzez wzajemną zmianę położenia $\mathrm{w}$ kierunku pionowym dwóch członów głównego mechanizmu. Odpowiednia czasowo-przestrzenna koordynacja położenia członów mechanizmu pozwala $\mathrm{w}$ sposób ciagły i przewidywalny nadawać odpowiedni kierunek ruchu pojazdu zgodnie z przyjętą trasą. Jednocześnie po przejechaniu przez rozjazd nastapi zmiana strony prowadzącej tak, aby przed następnym rozjazdem układ zapewniał możliwość wykonania ponownie powyżej opisanego manewru.

Poniżej na rys. 4. przedstawiono wstępne projekty kształty kabiny pojazdu PRT - SITIN.

\section{Zakres badanych przypadków i przykładowe wyniki}

Wstępne badania symulacyjne dynamiki ruchu pojazdu PRT prowadzone były w oparciu o trzy koncepcje rozwiązań układu jezdnego pojazdu PRT. W trakcie badań wykonano szereg symulacji, zgodnie $\mathrm{z}$ przyjętym planem. Badania pozwoliły wybrać model,
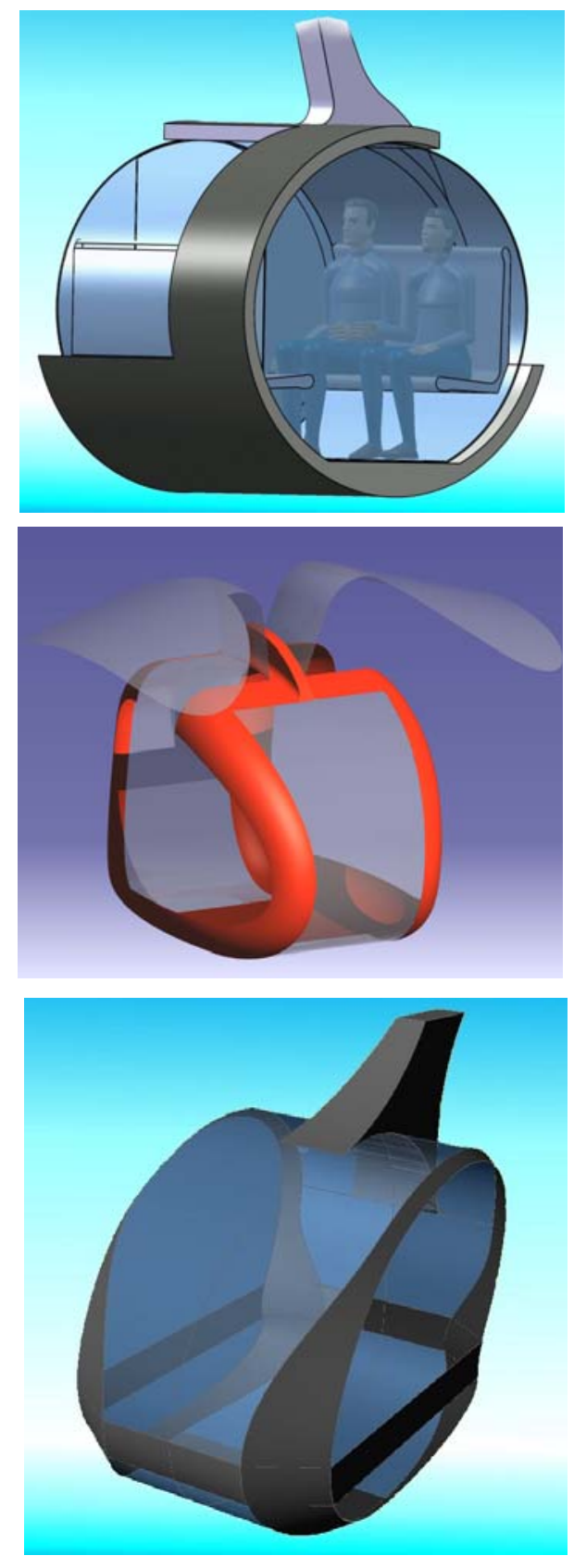

Rys. 4. Projekty kształtu kabiny pojazdu PRT - SITIN

który zostanie poddany szczegółowym analizom symulacyjnym przy wykorzystaniu pakietu MBS Adams (moduły: Adams/View oraz Adams/Solver). Obecnie model ten, tworzony w oparciu o zgłoszenie patentowe na wynalazek nt.: Układ napędowo-jezdny do pojazdów poruszających się po napowietrznych szynach jezdnych, zwłaszcza magistralach sieciowych inteligentnego systemu transportu miejskiego typu PRT; zgłoszenie P 383-748 z dnia 12.11.2007, którego współautorami są W. Choromański, G. Dobrzyński, J. Kowara jest na etapie modyfikacji i analiz.

Badania na uproszczonych modelach wykonano z zastosowaniem „sztywnej szyny”. Jako przejazd nominalny określono: rozpędzanie pojazdu do prędkości $50 \mathrm{~km} / \mathrm{h}$, przejazd przez rozjazd ze zmianą kierunku ruchu i zmniejszaniem prędkości jazdy do 
$30 \mathrm{~km} / \mathrm{h}$ oraz ponowny przejazd przez rozjazd. Następnie każdy $\mathrm{z}$ badanych przypadków poddano szeregu wymuszeniom:

0 - wymuszenie kinematyczne powodowane geometrią toru,

1 - wymuszenie siłowe w postaci podmuchu wiatru,

2 - wymuszenie w postaci przemieszczającej się masy wewnątrz kabiny,

Analizowano również zmiany parametrów sztywności i thumienia w kontakcie kół jezdnych $\mathrm{z}$ szynami i w dolnej podporze stabilizującej pojazd $\mathrm{w}$ poziomie.

Przykładowe wyniki podano na rysunkach 5, 6, 7, 8. Ruch analizowano w układzie współrzędnych poruszających się względem linii toru z prędkością scharakteryzowaną powyżej. Kierunek X jest kierunkiem poruszania się pojazdu, kierunek Y kierunkiem poprzecznym do kierunku ruchu. Dla poniższych przypadków zaobserwowano silną wrażliwość modelu na wychylenia przy działaniu wymuszeń 1 i 2 co prowadzi do pewnych ograniczeń w eksploatacji lub stosowania zaawansowanego sterowania parametrami mechanizmu podatnego zawieszenia kabiny. Wyraźnie widać znaczenie elementu podatnego (łączącego kabinę z układem napędowym - rys.2 pkt 2) w redukcji przyspieszeń i prędkości narastania przyspieszeń co ma szczególne znaczenie przy redukcji oddziaływań na organizm ludzki

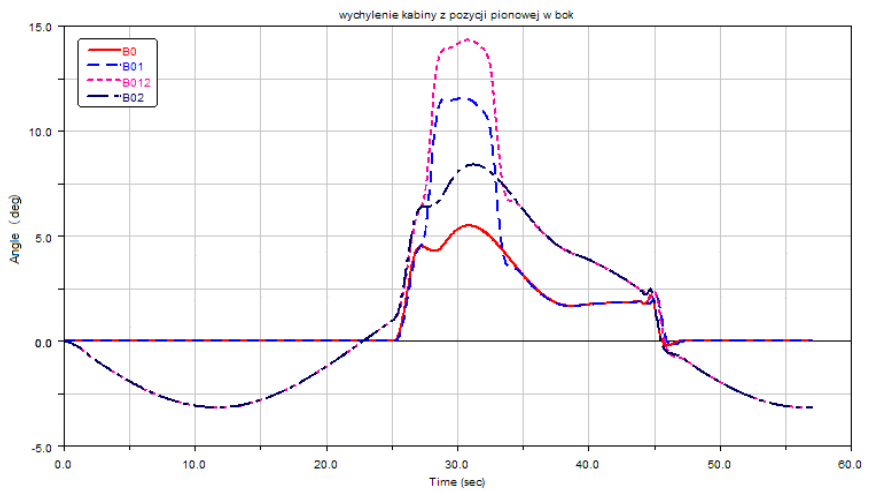

Rys. 5 Wychylenie kabiny dla modelu B (model symetryczny z amortyzacją kabiny) z uwzględnieniem opisanych w punkcie 3 . wymuszeń

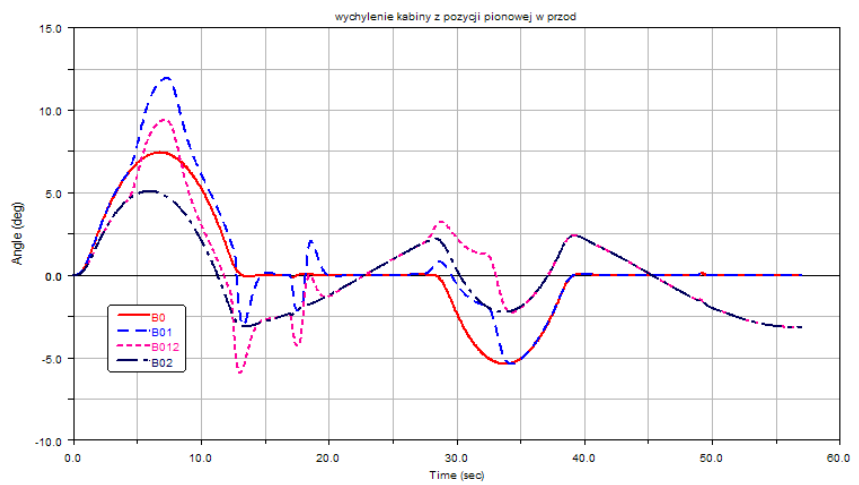

Rys. 6 Wychylenie kabiny dla modelu B (model symetryczny z amortyzacją kabiny) $\mathrm{z}$ uwzględnieniem opisanych w punkcie 3.wymuszeń

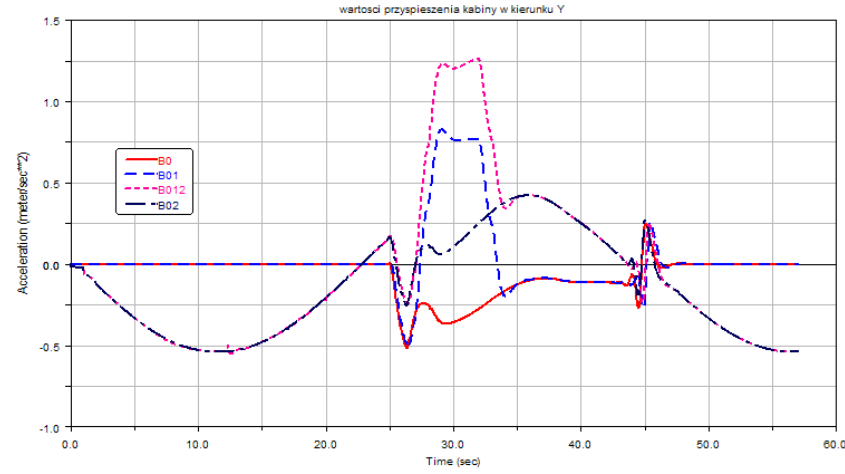

Rys. 7 Przyspieszenia oddziaływujące na pasażera dla modelu B (model symetryczny $\mathrm{z}$ amortyzacją kabiny) $\mathrm{z}$ uwzględnieniem opisanych w p. 3. wymuszeń

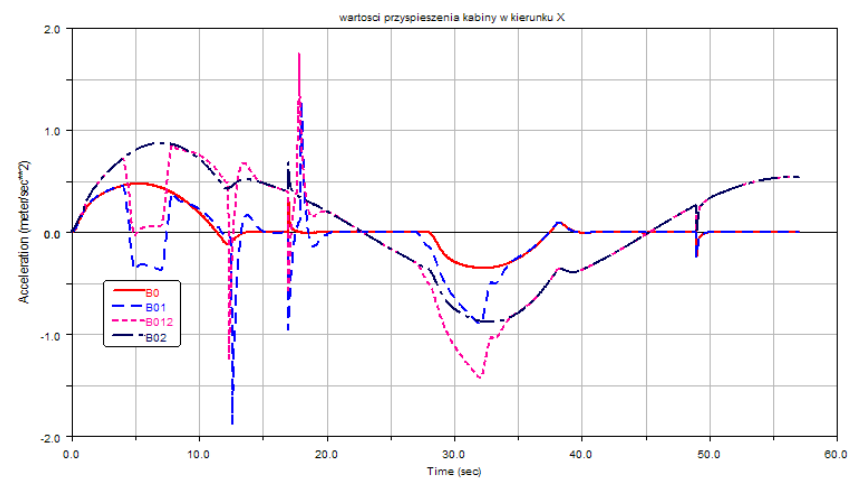

Rys.8 Przyspieszenia oddziaływujące na pasażera dla modelu B (model symetryczny $\mathrm{z}$ amortyzacją kabiny) $\mathrm{z}$ uwzględnieniem opisanych w p. 3. wymuszeń

\section{Wnioski}

Trudno jest dzisiaj jednoznacznie ocenić efektywność i przydatność systemów klasy PRT, zwłaszcza, ze nie dysponujemy żadnymi doświadczeniami z systemów już eksploatowanych. W literaturze $[1,2,3,4]$ rozpatruje się wdrożenie tego typu systemów:

1. Jako globalne rozwiązanie transportu publicznego w dużych aglomeracjach miejskich) (ang.High-Capacity Personal Rapid Transit),

2. Jako lokalne rozwiązanie w dużych aglomeracjach miejskich (np. obsługa największego węzła przesiadkowego w Europie WarszawaCentralna),

3. Jako rozwiązanie specyficznych potrzeb transportowych (transport w dużych centrach handlowych, transport w Warszawskim Parku Technologicznym),

4. Jako rozwiązanie transportowe w specyficznych miastach (np. Zakopane, Szczyrk),

5. Jako atrakcja turystyczna i swoista wizytówka miasta (koncepcja np. połączenia skarpy wiślanej z Ogrodem Zoologicznym) 
Niewątpliwie należy się spodziewać, że systemy transportu określane mianem Personal Rapid Transit zostaną wdrożone do użytku publicznego i w przyszłości staną się powszechne w użyciu. Wydaje się zatem uzasadnione prowadzenia dalszych badań,. $\mathrm{w}$ tym budowę prototypu i badań na prototypie.

\section{Literatura}

[1] Iring J., Fundamentals of Personal Rapid Transit, Lexington Books 1978,
[2] Anderson J.E, A Review of the State of the Art of Personal Rapid Transit, Journal of Advanced Transportation, Vol 34, No.1, pp.3-29, 2000,

[3] Choromanski W., Grabarek I, Problems of the Dynamics of an Intelligent Overhead Municipal Transport System International Association for Vehicle System Dynamics, Berkeley 2007 (conference proceedings, special edition of VSD in print), 2007,

[4] Choromanski W, Grabarek I, et al., Selected Problems of PRT, report of rector grant, Warsaw University of Technology (in polish), 2006 